\title{
Potential medicinal plants for improve the immune system from Borneo Island and the prospect to be developed as nanomedicine
}

\author{
Lutfi Chabib ${ }^{1,2, *}$, Wildan Khairi Muhtadi ${ }^{3}$, Muhammad Ikhwan Rizki $^{4}$, and Rifazul Aulia Rahman $^{4}$, Mohamad Rahman \\ Suhendri ${ }^{5}$, and Arif Hidayat ${ }^{6}$ \\ ${ }^{1}$ Department of Pharmacy, Islamic University of Indonesia, Jl. Kaliurang km. 14,5, Yogyakarta, 55584, Indonesia \\ ${ }^{2}$ Professional Pharmacy Education Program, Islamic University of Indonesia, Jl. Kaliurang km. 14,5, Yogyakarta, 55584, Indonesia \\ ${ }^{3}$ Faculty of Pharmacy, Gadjah Mada University, Bulaksumur, Yogyakarta, 555281, Indonesia \\ ${ }^{4}$ Lambung Mangkurat University, Jl. A. Yani km 36, Banjarbaru, Indonesia \\ ${ }^{5}$ Faculty of Medicine, Islamic University of Indonesia, Jl. Kaliurang km. 14,5, Yogyakarta, 55584, Indonesia \\ ${ }^{6}$ Chemical Engineering Department, Islamic University of Indonesia, Yogyakarta, 55584, Indonesia
}

\begin{abstract}
The immune system is a combination of cells, molecules, and tissues that play a role in preventing, detecting and eliminating a pathogen that enters the body. Indonesian society, hereditary and traditionally used medicinal plants (herbs) to increase immunity or immune system that fight the bacterias and pathogens. This paper aims to review the potential plants for immunomodulator from Borneo Island and the prospect to be developed as nanomedicines. The review is made using online and offline literature. Based on the literature, the immune system can be improved by various compounds from plants such as bawang dayak (Eleutherine palmifolia (L) Merr), kelakai (Stenochlaena palustris (Burm.f) Bedd), pasak bumi (Eurycoma longifolia Jack), kasturi (Mangifera casturi Kosterm.), binjai (Mangifera caesia), ramania (Bouea macrophylla Griff), gerunggang (Cratoxylum arborescens (Vahl) Bl) and akar kuning (Fibraurea chloroleuca Miers). In general, the mechanism of the plants to improve the immune system is by facing the cause of the disease directly as an effector and also work by regulating immunity. The medicinal plants also have prospects to be developed as nanomedicines.
\end{abstract}

\section{Introduction}

The immune system is the combination of cells, molecules, and tissues that play a role or in preventing, detecting and eliminating a pathogen that enters the body [1]. When the immune condition is decreasing, the body's defense against pathogen's attack will also decrease and the body is very susceptible to illness [2]. There are two types of responses generated by the immune system: innate, which inhibits the entry of microbes that successfully enter the host tissues rapidly, and adaptive, which is activated by the repeated exposure of pathogens and will memorize the pathogen so that the responses generated in the next infection will be much stronger [3].

Many diseases caused by weak defense of immune systems against pathogens such as HIV/AIDS, microbial infections (bacteria or viruses), allergies, herpes, malaria and more. One of the most dangerous diseases is HIV/AIDS, where the disease affects the immune system of its host and causes weakening of the immune system and makes it susceptible to be attacked by dangerous pathogens. Based on data from the Ministry of Health of the Republic of Indonesia in 2016, the number of HIV infections as many as 41.250 people [4]. The other disease that attacks the other immune system is malaria, which is caused by the plasmodium virus. The incidence of malaria in Indonesia based on the diagnostic is 19 per 1,000 population [5]. In Southeast Asia, there are 28 million cases of malaria with a death rate of 38 thousand people where $95 \%$ of deaths occur in 3 countries namely Indonesia, India, and Myanmar [6]. Therefore, substances that can be used to improve the immune system are required.

The diseases that attack the immune system requires a serious treatment such as increasing body immunity. The immune system can be increased by taking medicinal plants (herbs) to reduce the resistance caused by bacteria or pathogens. Medicinal plants work in the immune system not only as an effector that directly face the cause of the disease but also by regulating immunity [7]. Certain herbs possess immunomodulatory contents that modulate the function and activate the immune system. Stimulation and activation of the immune system regulated by $\mathrm{T}$ lymphocytes by TH-1 (CD 4+) will cause an increase in the protective properties of antigens that produce cytokines and activate macrophages [8]. Macrophages are the cells that play an important role in an immune response, which conduct phagocytosis or act as the antigen presenting cells (APC). The ability of plants in improving the immune system is caused by its chemical content. There are many kinds of compounds that possess immunostimulation activity, such as alkaloid, terpenoids, quinones, simple phenolic compounds, polysaccharides, peptides, glycoproteins, and nucleotides [7]. 
The use of nanotechnology in medicine is spreading rapidly throughout the world. Many pharmaceutical scientists are developing nanomedicine using the active substances from synthetic materials and also natural products. The development of herbal nanomedicines is growing rapidly due to an increase of the use of natural products as the treatment of many diseases [9]. The ability to cross the cell membranes, including the blood-brain barrier, gain access to cells and also translocate around the body via blood and lymph, make nanoparticle a promising tool for delivering drugs to the site of action [10]. In this review, we provide various plants live in Borneo Island that contain compounds with activity as an immunomodulatory and potential to be developed as nanomedicines.

\section{The Plants in Borneo with the Ability to Improve the Immune System}

\subsection{Bawang Dayak (Eleutherine palmifolia(L) Merr)}

Results of phytochemical screening of the root of bawang dayak showed the existence of secondary metabolites such as alkaloids, glycosides, flavonoids, phenolic, quinones, steroids, astringent tannins and essential oils. The leaves and roots of this plant also contain flavonoids and polyphenolic compounds [11]. In another journal stated that the efficacy of the root ethanol extract as an antioxidant derived from secondary metabolites such as triterpenoids, flavonoids, phenolic, alkaloids and tannins. Flavonoids contained in this plants is proven to stimulate the immune system by increasing the activity of macrophages and $\mathrm{T}$ lymphocytes and also known that the ethanol extract of this plants showed the ability as an immunomodulator in mice and produce immunoglobulin such as immunoglobulin $\mathrm{G}$ (IgG) and immunoglobulin $\mathrm{M}$ (IgM) [12]. Flavonoids also showed immunostimulant activity by stimulating the human mononuclear cell to secrete cytokines such as IL- $1 \beta$, IFN- $\gamma$, and TNF- $\alpha$, which are able to induce the death and differentiation of U973 cells, which play a role in the progression of leukemia disease [13].

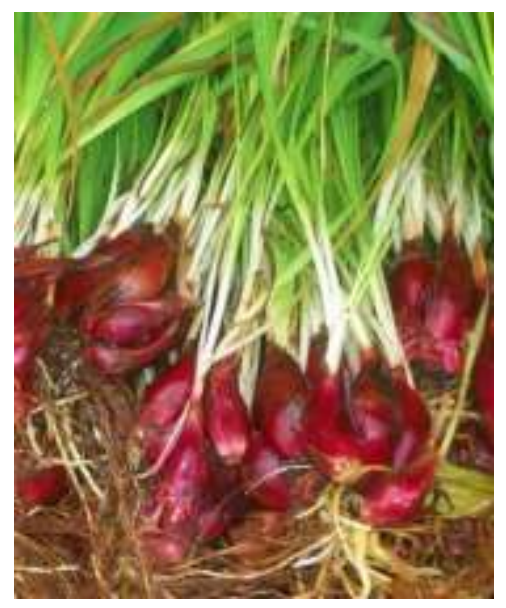

Fig 1. The root of bawang dayak (Eleutherine palmifolia $(\mathrm{L})$ Merr) [14]

\subsection{Kelakai (Stenochlaena palustris (Burm.f) Bedd)}

Kelakai (Stenochlaena palustris (Burm.f) Bedd) is a typical wetland (swamp) plant in South Kalimantan and a favorite food for Dayak people in Central Kalimantan. The Kenyah Dayak tribe uses this plant empirically for the treatment of anemia, fever reliever, and skin diseases. In the extract kelakai found the main bioactive substances are quercetin flavonoids that have anti-inflammatory effect. The total flavonoid contained in aqueous water extract was $14.5 \mu \mathrm{g} / \mathrm{ml}$. Other ingredients in plant kelakai such as alkaloids and steroids [6]. Research has shown that extracts of the kelakai in doses of $100 \mathrm{mg} / \mathrm{kg}$ play a role for the immunomodulator in order to modulate the production of IL-10 cytokines in P. berghei infection. The role of IL-10 is the response of T-helper cells in malaria to prevent Th1 cells proliferating, thus suppressing the production of IFN- $\gamma$, IL- 6 , TNF- $\alpha$ by T cells, which in turn will neutralize the pathology of macrophages by inhibiting IFN secretion $-\gamma$ and TNF- $\alpha$ in cerebral malaria [15].

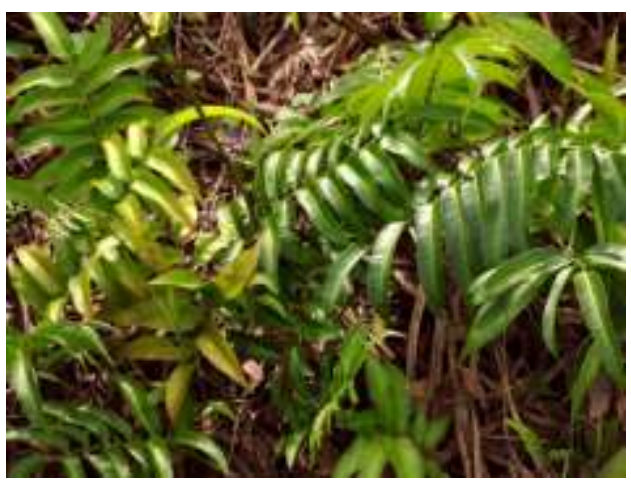

Fig 2. Kelakai (Stenochlaena palustris (Burm.f) Bedd) [16]

\subsection{Pasak Bumi (Eurycoma longifolia Jack)}

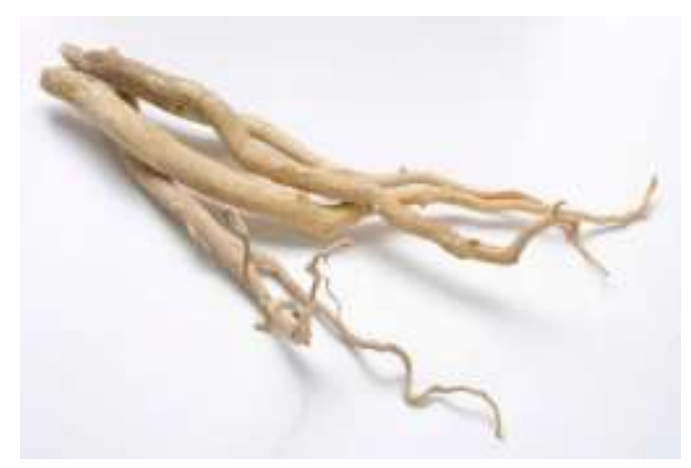

Fig 3. Root of pasak bumi (Eurycoma longifolia Jack) [19]

The bioactive contents of the root from pasak bumi possess anticancer, chemopreventive, and immunomodulatory effects. The bioactive compounds contained in this plant include quassinoids, flavonoids, and alkaloids (9-methoxycantin-6-on alkaloids and canthinone alkaloids). The mechanism of quassinoids as an immunomodulatory is by increasing the in vitro secretion of IL-12. IL-12 is a congenital immune response amplifier whose function activates macrophages against 
microbial stimuli by developing the function of NK cell effector [17]. In the other research, quassin, which is the member of the quassinoids group, showed its ability to produce the derivatives of nitric oxide in order to kill the intracellular Leishmania parasites. Quassin was also found able to increase the release and mRNA expression of TNF- $\alpha$, which is the inflammatory cytokine that plays a role in the eradication of Leishmania parasites. The abilities of quassin found in the study proven its potentiality as an immunomodulator to increase immunity for the treatment of chronic infectious diseases [18].

\subsection{Kasturi (Mangifera casturi Kosterm.)}

Kasturi is an endemic plant found in the South Kalimantan area which is commonly used by local people to be consumed due to its sweet taste and also has a distinctive aroma of fun. Phytochemical screening and preliminary tests on kasturi's tree trunks were reported to contain bioactive substances such as terpenoids, steroids, and saponins, and it was proposed that the methanol extract of kasturi also had bioactive components such as terpenoids / streroids and phenolics also contained flavonoids [20, 21]. The kasturi fraction also has an antibacterial content [22]. The isolated terpenoids from Mangifera casturi fruit with the concentration of 6,25 $\mu \mathrm{g} / \mathrm{mL}$ and $12,5 \mu \mathrm{g} / \mathrm{mL}$ indicated immunomodulatory activity. The terpenoids enhanced the ability of macrophage to phagocytize the latex beads which indicated with the latex beads particles swallowed into the macrophage cells [23].

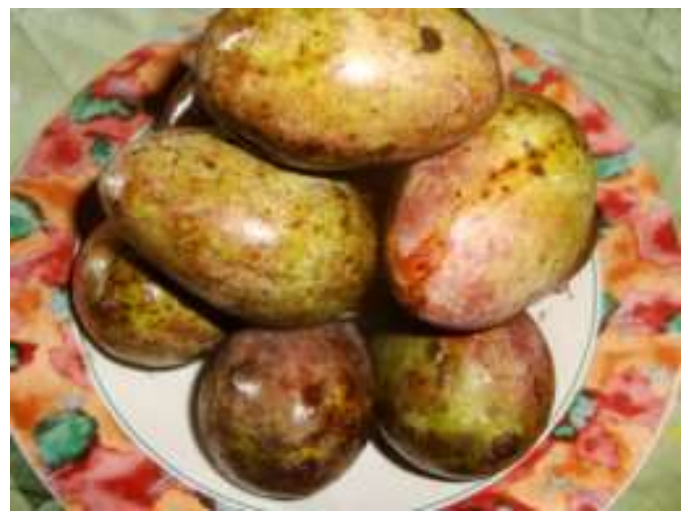

Fig 4. Kasturi (Mangifera casturi Kosterm.) [24]

\subsection{Binjai (Mangifera caesia)}

Binjai is including in manga type with oval leaf shape, thick, clay, rather large, absent bone, fruit weight between 192-316 g, thin-skinned, soft young flesh and soft when ripe, rough fibrous, and the smell of typical fruits sting. Large seeds with elongated round shape [25]. Binjai (Mangifera caesia) is one of the Mangifera genus, which is often consumed by the people of South Kalimantan, has a sour taste and a little sweet taste with a distinctive taste and commonly used as a mixture in sauce. The leaves of this plant contain bioactive substances such as flavonoids, which are compounds that have functions as antiinflammatory, anti-cancer, anti-leukemia, anti malarial and can be used as HIV treatment [26]. Another study found that binjai plants contain a compound that is not found in other plant species that is alkenilfenol which has activity as an antioxidant [27]. The results of phytochemical screening performed on the roots and stems of binjai and kasturi plants contain saponins. Saponin is a secondary metabolite compound belonging to terpenoid groups, ie compounds containing isoprene skeletons $\mathrm{CH}_{2}=\mathrm{C}\left(\mathrm{CH}_{3}\right)-\mathrm{CH}=\mathrm{CH}_{2}$ [28]. Saponin has the ability as an immunostimulant by stimulating the response of innate immune, which makes saponin a promising compound to be used as vaccine adjuvant [29].

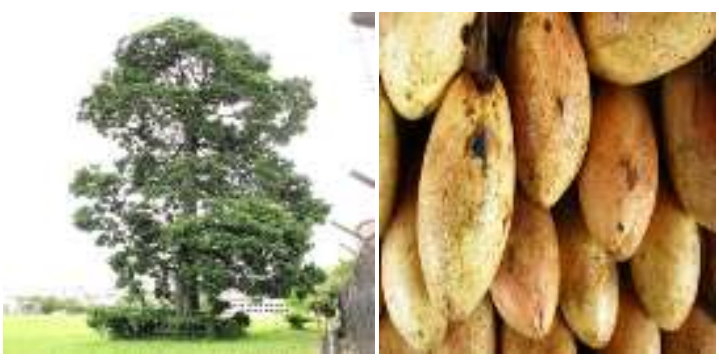

Fig 5. The tree and fruit of Binjai (Mangifera caesia) [30]

\subsection{Ramania (Bouea macrophylla Griff)}

Ramania (Bouea macrophylla Griff) is a typical plant of the Borneo region. In the leaves of ramania plants contain a large number of substances such as flavonoids, saponins, triterpenoids. The secondary compound of flavonoids acts as an antioxidant and accelerates wound healing by the mechanism of accelerating the proliferation of fibroblast cells and the production of collagen fibers so that it can treat wounds quickly and the cell turnover will accelerate and will surely enhance the body's immune system [31]. Another immunostimulant activity of flavonoids was found through its ability to inhibit the growth Legionella pneumophila in macrophages [32]. The other content of ramania is vitamin C, which is 172.4 $\mathrm{mg}$ in 100 grams of its fruits. Vitamin $\mathrm{C}$ possesses the ability to increase the immune system [33]. Vitamin A is also found in ramania fruits with amount of 1,020 IU that can be seen from the color of its orange fruit flesh [34].
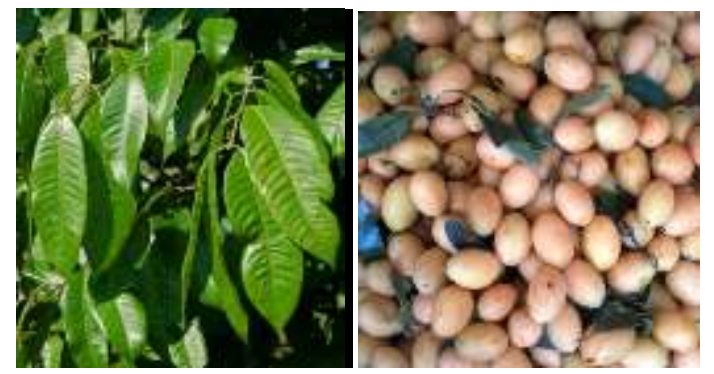

Fig 6. The leaf and fruit of Ramania (Bouea macrophylla Griff) [35]

\subsection{Gerunggang (Cratoxylum arborescens (Vahl) BI)}

This plant is commonly found in the wet areas (swamps) in Kalimantan. The study conducted by Yusro suggests 
that the bark extracts possess the ability as the treatment of headache and cancer. The phytochemical screening of the bark of gerunggang showed that it contains several compounds such as tannin, saponin, flavonoids, and quinone. Flavonoids have properties for anti-virus, antimicrobial, anti-inflammatory and healing subcutaneous capillary hemorrhage, while saponin has the function as an immunostimulant that stimulates the immune system in the body [36].

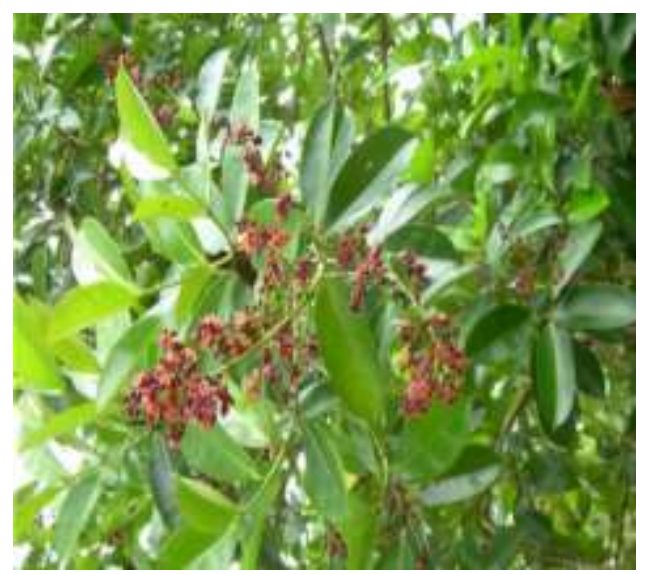

Fig 7. Gerunggang (Cratoxylum arborescens (Vahl) Bl) [37]

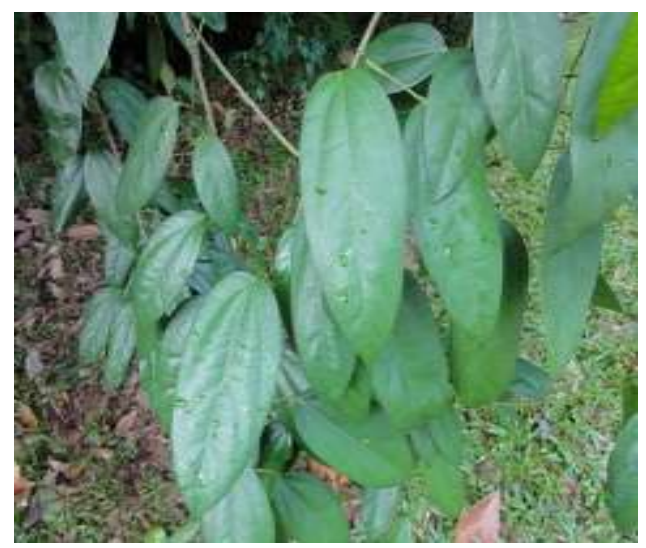

Fig 8. The leaves of akar kuning (Fibraurea chloroleuca Miers) [41]

\subsection{Akar Kuning (Fibraurea chloroleuca Miers)}

Dayak community in Kalimantan uses akar kuning as the treatment of abdominal pain, eye drops and yellow pain medication. There are secondary metabolite compounds contained in $F$. chloroleuca such as alkaloid compounds that are commonly found in the stems, roots and leaves. The other studies shown that alkaloids in the stems and roots of $F$. chloroleuca have similar species. The other secondary metabolite compounds are terpenoid compounds, both on stems, leaves and roots. Several other studies also suggested that the compounds contained in the $F$. chloroleuca plant are berberine, which is an alkaloid that has been used in a long time as a medicine. The type of bioactive compound that can be identified is 8-oxoprotoberberine [38]. Berberine possesses activity as an immunostimulant by increasing the ability of macrophages to kill bacteria swallowed in the body [39]. Another study found that berberine increased the production of interleukin-12, which stimulated the immunoregulatory activity by inhibiting the profile of $\mathrm{T}$ helper- 2 cytokine in $\mathrm{CD}^{+}$cells. The findings proven that medicinal plants containing berberine can be used as the therapy of allergic diseases, particularly the T helper type 2 cell-mediated immune disease [40].

\section{The Prospects of Nanomedicine from Medicinal Plants as Immunostimulant}

There are many medicinal plants containing compounds that possess immunomodulatory activity, either suppress or stimulate the immunity that can be used in the treatment of most disease. Many studies have been conducted to explore the most effective delivery methods to deliver the compounds to get the significant immunomodulatory effect in the human body. One of the methods that attract much attentions is to formulate them as the nanomedicine, which makes the drug in the form of nanoparticles (NPs). This method is being developed widely nowadays. NPs are very small forms of material substances, measuring from 1 to 100 nanometers, which make them possess large surface area. Due to the very small size and large surface area, NPs possess unique abilities. For example, NPs readily cross the cell membranes, including the bloodbrain barrier, possibly to gain access to cells and also translocate around the body via blood and lymph. The ability to access the inside of the cells makes them a promising tool for delivering drugs to the site of action [10].

The study conducted by Seo found that $R$. Coreanus extract-encapsulated gelatin nanoparticles with an average size of $143 \pm 18 \mathrm{~nm}$ that had been produced in the study possessed the possibility to be targeted to the particular tissues to achieve a higher local concentration compared to the ingestion of the crude extract only. The nanoparticles also showed a low toxicity and high biocompatibility. The immunomodulatory effects of $R$. Coreanus extract-encapsulated gelatin nanoparticles, that were determined in T-cells, B-cells, and natural killer (NK) cells, were found with a higher potency compared with the crude extract or ferulic acid as the control. There were two immune activities of the nanoparticles attracting attention in the study. First, the proliferation of B- and Tcells. It was found that the nano-encapsulated extracts induced a significantly higher proliferation in T- and Bcells, which was $\sim 3.4 \times$ control and $\sim 2.9 \times$ control respectively, while the extract only showed $\sim 1.8 \times$ control and $\sim 1.9 \times$ control in T- and B-cells respectively. Second, the proliferation of natural killer (NK) cells. The primary function of NK cells is to eliminate aberrant cells, including virally infected and tumorigenic cells. The result showed that the nano-encapsulated extract increases the proliferation of $\mathrm{NK}$ cells extremely compared to control and that the quite significant effect compared to the crude extract only. It was assumed that the result was caused by the ability of nanoparticle to induce cellular penetration and uptake, that lead to a higher local concentration [42]. 
Another study conducted by Rather found that green synthesis of silver nanoparticles (G-AgNPs) from Azadirachta indica (neem) possessed the highest phagocytic activity compared to the control (the fish which were used as the experimental animal were given no treatment) and neem extract only. It might be due the G-AgNP has activated an alternative pathway that only can be done by nanoscale particles that increase the immunomodulation activity. Nevertheless, the mechanism of immunomodulatory effects of G-AgNPs needs to be investigated further [43].

The result of the two studies indicates that there is a possibility to formulate nanomedicines of medicinal plants that possess immunomodulatory activity. It is assumed that the medicinal plants from Borneo Island that had been reviewed in this article also possible to be formulated as the nanomedicines.

\section{Conclusion}

There are many plants that grow in Borneo Island that can be used to improve the immune system such as bawang dayak (Eleutherine palmifolia (L) Merr), kelakai (Stenochlaena palustris (Burm.f) Bedd), pasak bumi (Eurycoma longifolia Jack), kasturi (Mangifera casturi Kosterm.), binjai (Mangifera caesia), ramania (Bouea macrophylla Griff), gerunggang (Cratoxylum arborescens (Vahl) $\mathrm{Bl}$ ) and akar kuning (Fibraurea chloroleuca Miers). The medicinal plants are assumed to have the possibility to be developed as the immunomodulatory nanomedicines that possess many advantages.

We would like to acknowledge Pharmacy Nanoscience, Pharmaceutical Technology Laboratory, Department of Pharmacy, Islamic University of Indonesia. We also would like to address a gratitude to the grant of Penelitian Madya DPPM UII. Authors declare no conflict of interest.

\section{References}

1. J. Kelly, Understanding the Immune System How It Works, NIAID Science Education, USA, (2007).

2. D. Mayasari, A. Pratiwi, Relation between immune respond and stress with the level of typhoid fever recurrence in the population of Puskesmas Colomadu Karanganyar region, Jurnal Berita Ilmu Keperawatan, 2, 13-18, (2009).

3. P. J. Delves, I. M. Roitt, The Immune System. First of two parts, N Engl J Med, 343, 37-49, (2000).

4. Ministry of Health of Republic of Indonesia, Data and information of Indonesian health profile 2016, Ministry of Health RI, (2017).

5. Ministry of Health of Repulic of Indonesia, Health profile of Indonesia, Ministry of Health RI, Jakarta, (2015).

6. D. P. N. H. Margono, E. Suhartono, H. Arwati, Potentiality of kelakai (Stenochlaena palustris (Burm.f) Bedd) extract against the level of tumor necrosis factor-alfa (TNF- $\alpha)$ in the BALB/c mice infected with Plasmodium Berghe Anka, Berkala Kedokteran, 12, 77-85, (2016).

7. Y. P. Utami, Aliyah, R. Syukur, Immunostimulant effect combination syrup of Carthamus tinctorius $L$. and Eleutherine palmifolia extracts on mice (Mus musculus), JST Kesehatan, 6, 179-184, (2016).

8. A. N. Toemon, Effects of orally bawang dayak (Eleutherine bulbosa (Mill.) Urb.) root ethanol extract on Balb/c mice against the prevention of the decrease of IFN- $\gamma$-expressed cell amounts and the increase of CD 14-expressed cell amounts, Jurnal Biosains Pascasarjana. 17, 1-14, (2015).

9. A. Pandey, G. Pandey, Usefulness of nanotechnology for herbal medicines, Plant Archives, 13, 617-621, (2013).

10. K. S. Rao, A. Ghorpade, V. Labhasetwar, Targeting anti-HIV drugs to the CNS, Expert Opin Drug Deliv, 6, 771-784, (2009).

11. R. Puspadewi, P. Adirestuti, R. Menawati, Efficacy of bawang dayak (Eleutherine palmifolia (L.) Merr.) root as the skin antimicrobial herbal, Kartika Jurnal Ilmiah Farmasi, 1, 31-37, (2013).

12. A. B. Carmelita, Effects of orally bawang dayak (Eleutherine palmifolia (L.) Merr.) root extract on $\mathrm{BALB} / \mathrm{c}$ mice against the prevention of the decrease Germinal Center parameters on the lymph gland and IgG serum concentration, Jurnal Biosains Pascasarjana, 18, 1-13, (2016).

13. D. Y. Liao, Y. C. Chai, S. H. Wang, C. W. Chen, M. S. Tsai, Antioxidant activities and contents of flavonoids and phenolic acids of Talinum triangulare extracts and their immunomodulatory effects, J Food Drug Anal, 23, 294-302, (2015).

14. Anonymous, https://id.wikipedia.org/wiki/Bawang dayak, accessed 23 September 2017.

15. D. P. N. H. Margono, E. Suhartono, H. Arwati, Effects of kelakai (Stenochlaena palustris (Burm.f) $B e d d$ ) extract against the level of interleukin-10 (IL10) on mice, Medical Laboratory Technology Journal, 2, 31-36, (2016).

16. Anonymous, https://id.wikipedia.org/wiki/Lemidi, accessed 23 September 2017.

17. Arifah, A. $\mathrm{N} \&$ Nurkhasanah, The effect of ethyl acetate fraction of ethanolic extract of pasak bumi (Eurycoma longifolia, Jack) on macrophages phagocytic activity in vitro, Pharmaciana, 4, 9-14, (2104).

18. S. Bhattacharjee, G. Gupta, P. Bhattacharya, A. Mukherjee, S. B. Mujumdar, A. Pal, S. Majumdar, Quassin alters the immunological patterns of murine macrophages through generation of nitric oxide to exert antileishmanial activity, $\mathrm{J}$ Antimicrob Chemother, 63, 317-324, (2009).

19. Anonymous, http://www.eurytest.com/science/, accessed 23 September 2017.

20. N. Fakhrudin, P. S. Putri, Sutomo, S. Wahyuono, Antiinflamatory activity of methanolic extract of 
Mangifera casturi in thioglycollate-induced leukocyte migration on mice, Trad Med J, 18, 151156, (2013).

21. Sutomo, N. Agustina, Arnida, Fadilaturrahmah, Pharmacognostic study and nonspecific parameter test of the stem bark methanolic extract of kasturi (Mangifera casturi Kosterm.), Jurnal Pharmascience, 4, 94-101, (2017).

22. K. Rosyidah, S. A. Nurmuhaimina, N. Komari, M. D. Astuti, Antibacterial activity of the saponin fraction of the stem bark of kasturi (Mangifera casturi), Alchemy, 1, 53-103, (2010).

23. Sutomo, S. Wahyuono, E. P. Setyowati, A. Yuswanto, Activity of Mangifera casturi Kosterm. fruit isolates as an immunomodulator in vitro, Prosiding Seminar Nasional \& Workshop "Perkembangan Terkini Sains Farmasi \& Klinik 5", 260-266, (2015).

24. Anonymous,

https://en.wikipedia.org/wiki/Mangifera_casturi, accessed 23 September 2017.

25. M. Noor, M. Saleh, H. Subagio, Potency of biodiversity of fruit plants in swamp land and its utilization, Prosiding Seminar Nasional Masyarakat Biodiversitas Indonesia, 1, 1348-1358, (2015).

26. M. Syafarina, I. Taufiqurrahman, Edyson, Difference of total flavonoid between natural and artificial drying stage on binjai (Mangifera caesia) leaf extract, Jurnal Kedokteran Gigi, 1, 84-88, (2017).

27. K. Rosyidah, Siska, M. D. Astuti, Isolation of the antioxidant compounds from the stem bark of binjai (Mangifera Caesia), Jurnal Sains dan Terapan, 5, 814, (2011).

28. K. Mustikasari, D. Ariyani, The study potency of binjai (Mangifera caesia) and kasturi (Mangifera casturi) as antidiabetic by phytochemistry screening on roots and stem, Sains dan Terapan Kimia, 2, 6473, (2008).

29. H. Top, N. B. Sarikahya, A. Nalbantsoy, S. Kirmizigul, Immunomodulatory, hemolytic properties and cytotoxic activity potent of triterpenoid saponins from Cephalaria balansae, Phytochemistry, 137, 139-147, (2017).

30. Anonymous,

http://www.fruitipedia.com/binjai_mangifera_caesi a.htm, accessed 23 September 2017.

31. A. Rahman, I. Taufiqurrahman, Edyson, Difference of the total flavonoids between the method of maseration and soxhletation on ramania (Bouea macrophylla Griff) leaves extract, Jurnal
Kedokteran Gigi, 1, 22-27, (2017).

32. M. Vajdy, Immunomodulatory properties of vitamins, flavonoids and plant oils and their potential as vaccine adjuvants and delivery systems, Expert Opin Biol Ther, 11, 1501-1513, (2011).

33. S. Susi, Utilization potency of the nutrient of exotic fruits from South Kalimantan, Jurnal Ziraa'ah, 39, 144-150, (2014).

34. S. S. Antarlina, Identification of physicochemical properties of local fruits of Kalimantan, Buletin Plasma Nutfah, 15, 80-91, (2009).

35. Anonymous, https://en.wikipedia.org/wiki/Bouea_macrophylla, accessed 23 September 2017.

36. F. Yusro, Rendement of ethanol extract and the phytochemical test of three types of medicinal plants of West Kalimantan, Jurnal Tengkawang, 1, 29-36, (2011).

37. Sabah Forestry Department, Serungan/geronggang tree species (Cratoxylum arborescens). Sabah, (2007).

38. M. S. R. Wahyuningsih, S. Wahyuono, D. Santosa, J. Setiadi, Soekotjo, S. M. Widiastuti, R. Rakhmawati, D. S. C. Wahyuni, Exploration of Central Kalimantan's forest plants as bioactive compound resources, Biodiversitas, 9, 169-172, (2008).

39. C. Li, L. Yan, Y. Jing, L. Xu, Y. Liang, H. Wei, B. $\mathrm{Hu}, \mathrm{H}$. Pan, Q. Zha, D. Ouyang, X. He, Berberine augments ATP-induced inflammasome activation in macrophages by enhancing AMPK signaling, Oncotarget, 8, 95-109, (2017).

40. T. S. Kim, B. Y. Kang, D. Cho, S. H. Kim, Induction of interleukin-12 production in mouse macrophages by berberine, a benzodioxoloquinolizine alkaloid, deviates CD4+ T cells from a Th2 to a Th1 response, Immunology, 109, 407-414, (2003).

41. Anonymous, http://indiabiodiversity.org/species/show/268035, accessed 23 September 2017.

42. Y. C. Seo, W. Y. Choi, C. G. Lee, S. W. Cha, Y. O. Kim, J. Kim, G. P. C. Drummen, H. Y. Lee, Enhanced immunomodulatory activity of gelatinencapsulated Rubus coreanus Miquel nanoparticles, Int J Mol Sci, 12, 9031-9056, (2011).

43. M. A. Rather, I. A. Bhat, N. Sharma, A. Gora, P. A. Ganie, R. Sharma, Synthesis and characterization of Azadirachta indica constructed silver nanoparticles and their immunomodulatory activity in fish, Aquacult Res, 2016, 1-13, (2016) 